journal homepage: https://www.acquesotterranee.net/

\title{
Determining initial viability of local scale managed aquifer recharge projects in alluvial deposition systems
}

\section{Determinazione preliminare della fattibilita' dei progetti di ricarica degli acquiferi a scala locale in depositi alluvionali}

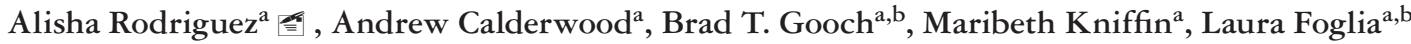 \\ a Department of Land, Air and Water Resources, University of California, Davis - email: amarodriguez@ucdavis.edu - ajcalderwood@ucdavis.edu \\ ${ }^{\mathrm{b}}$ Larry Walker Associates - email: lfoglia@ucdavis.edu
}

\section{ARTICLE INFO}

Ricevuto/Received: 16 February 2021 Accettato/Accepted: 03 May 2021 Pubblicato online/Published online: 30 June 2021

Editor: Daniele Pedretti

Citation:

Alisha Rodriguez, Andrew Calderwood, Brad T. Gooch, Maribeth Kniffin, Laura Foglia, (2021) Determining initial viability of local scale managed aquifer recharge projects in alluvial deposition systems. Acque Sotterranee - Italian Journal of Groundwater, 10(2), 7 - 18, https://doi.org/10.7343/as-2021-500

Correspondence to: Alisha Rodriguez amarodriguez@ucdavis.edu

\section{Keywords: groundwater flow, groun- dwater recharge, Managed Aquifer Re- charge, beterogeneity. \\ Parole chiave: flusso delle acque sotterranee, ricarica, ricarica del- le falde in condizioni controllate, eterogeneità.}

Copyright: (C) 2021 by the authors Licensee Associazione Acque Sotterranee. This is an open access article under the CC BY-NC-ND license: http://creativecommons.org/licenses/bync-nd/4.0/

\section{Riassunto}

Lo sfruttamento eccessivo delle acque sotterranee è uno dei maggiori problemi idrici del nostro tempo. In California, decenni di sfruttamento hanno portato all'approvazione del Sustainable Groundwater Management Act (SGMA), che richiede lo sviluppo di piani per la gestione sostenibile delle risorse idriche per tutti gli acquiferi, compresi acquiferi che al momento non sono sovrasfruttati ma che potrebbero esserlo in futuro. Molte agenzie per le risorse hanno iniziato a usare la ricarica degli acquiferi in condizioni controllate (MAR Managed Aquifer Recharge), nel loro portafoglio di azioni per dimostrare o ottenere in futuro la sostenibilità nell'uso delle acque sotterranee. Mappe del suolo sono state utilizzate in passato per determinare la adeguatezza di questi siti di ricarica. Tuttavia, queste mappe del suolo non considerano i percorsi ad alta permeabilità che possono esistere nel sottosuolo, che hanno il potenziale per fornire una ricarica ad alta efficienza alla falda freatica. Questo lavoro dimostra l'utilità di creare modelli geostatistici ad alta risoluzione e alta densità di dati. Utilizzando questi modelli si possono generare molte diverse realizzazioni che rappresentano le caratteristiche del sottosuolo, che possono consentire ai gestori di comprendere meglio la potenziale diffusione in falda dell'acqua applicate in superficie attraverso MAR. Questi modelli geostatistici sono stati incorporati in un software di connettività per valutare i potenziali percorsi di diffusione dell'acqua nel sottosuolo. I risultati preliminari mostrano che il sito di studio ha il potenziale per fornire una ricarica efficiente alla falda freatica, soprattutto in alcune aree. L'obiettivo di questo documento è enfatizzare l'importanza dell'utilizzo di dati geologici per comprendere la fattibilità iniziale dei siti di ricarica, senza dover sviluppare immediatamente modelli numerici per la simulazione dei flussi nella falda. Le analisi di connettività dei percorsi ad alta conducibilità potrebbero rivelarsi un primo passo vantaggioso quando si analizza la fattibilità dei siti di ricarica.

\section{Abstract}

Critical groundwater overdraft is one of the greatest water issues of our time. In California, decades of overdraft have resulted in the passage of the 2014 Sustainable Groundwater Management Act, which requires critically overdrafted groundwater basins to create groundwater sustainability plans for future groundwater management. Many managers are using managed aquifer recharge (MAR) in their overall sustainability portfolio, in an attempt to balance groundwater use. Soil maps bave been used in the past to determine viability of managed aquifer recharge sites. However, soil maps do not account for the bigh permeability pathways that exist in the subsurface, which have the potential to provide high efficiency recharge to the water table. This paper emphasizes the utility of creating data dense fine resolution geostatistical models and generating many realizations of the subsurface, which can then be used for analysis to understand the variability in recharge potential for specific recharge sites. These geostatistical realizations were investigated using connectivity metrics to evaluate the spread of highly conductive pathways throughout the subsurface. Connectivity analyses of bigh conductivity pathways show confidence that the study site- three vineyards located in the floodplain between the Cosumnes River and Deer Creek in Elk Grove, CA - has the potential to provide efficient recharge to the water table. These connectivity analyses can be completed prior to running computationally expensive and time intensive groundwater models and can be used as a way to understand variance between realizations of these geostatistical models. 


\section{Inroduction Background}

Around the world groundwater overdraft is slowly becoming a visible problem as both domestic and agriculture wells run dry (Taylor et al. 2012). The Central Valley of California provides an opportune place to study overdraft as continued groundwater over-pumping has led to land subsidence in the San Joaquin Valley (Sneed and Brant 2015), seawater intrusion in coastal areas (Barlow and Reichard 2010), and streamaquifer disconnection throughout the state (Barlow and Leake 2012). Climate change is expected to increase the frequency of droughts and alter surface water availability due to less robust snowpack water storage, making the need for reliable groundwater resources even more important (Jimenez et al. 2014; Swain et al. 2018; Cayan et al. 2005). California passed the Sustainable Groundwater Management Act (SGMA 2014), the first major groundwater law in California aimed at mitigating worsening groundwater conditions, to prepare for continued strains on the state's groundwater supply. This law requires that a group of stakeholders in a subbasin with critical overdraft create a Groundwater Sustainability Plan to balance the water budget by either reducing existing groundwater use or finding new sources of recharge (SGMA 2014).

Groundwater managers in overdrafted basins are considering incorporating Managed Aquifer Recharge (MAR) in their groundwater sustainability plans as one method to increase recharge. MAR involves diverting excess surface water when available (most likely in winter/spring in California) to highly conductive areas to allow for rapid recharge to the water table below (Dillon et al. 2009, Bouwer 2002). This method of groundwater banking is appealing because it allows for continued groundwater use and infiltration of surface water that would otherwise flow to the ocean (Kocis and Dahlke 2017). Agricultural-MAR (Ag-MAR), the practice of flooding agricultural fields during the dormant seasons using high magnitude flows, has been considered as an effective means of replenishing the groundwater table during the dormant season (Bachand 2014). Studies of Ag-MAR on alfalfa have shown great potential for recharge without negatively affecting crop yield (Dahlke et al. 2018). A study that measured how an increase of water on agricultural fields could negatively affect water quality and nitrate leaching concluded that vineyards may be effective Ag-MAR sites, because of the lessened concern of nitrogen leaching when compared to other crops such as tomatoes or almonds (Waterhouse et al 2020).

One challenge to an effective MAR project is finding locations of efficient and convenient recharge. There are surface maps that characterize highly conductive soils in the region, such as the Soil Agricultural Groundwater Banking Index (SAGBI) (O'Geen 2015), and these maps have been used to identify suitable sites for recharge projects. However, research focused on MAR suitability found that surface level soil characteristics alone may not always be reliable in finding the most efficient recharge sites (Maples et al. 2019). This is because in alluvial depositional systems, analysis of the deeper geology is needed to identify highly conductive connected pathways, that have the potential to move a large amount of water from the surface to the groundwater table quickly (Weissmann et al. 2004). These highly conductive pathways are not necessarily correlated to the surface characteristics of a site. Because of this, more geologic inquiry must be completed to have a clear understanding of recharge potential at specific study sites.

Most groundwater models account for the geology of the system in a layer-cake fashion, and while this can be acceptable when understanding how much bulk flow moves throughout the system (Fogg et al. 2000), it does not account for the interconnected pathways that exist in alluvial depositional systems (Weissmann et al. 2004). Highly conductive pathways formed in glacier deposition, defined as Incised Valley Fills (IVF's) (Weissmann et al. 2004) are responsible for areas of high efficiency water movement in the American River Valley (Meirovitz 2010). There is the potential that these American River Valley IVF's underly the modern Cosumnes River (Meirovitz 2010). Thus, it is important to characterize the impact of these high conductivity interconnected pathways on MAR. The use of a geostatistical modeling program that can allow for stochastic-based simulation of these probable interconnected pathways can help determine MAR site suitability.

The goal of this research is to use newly available data to create realizations of a stochastic geologic model for a proposed MAR site in Elk Grove, California. Access to large amounts of geologic data, an extensive monitoring network, and previous research completed at the site make this location a perfect site for determining the impact of specific geologic controls (i.e., connectivity, vertical facies distribution) on the feasibility of future MAR. This paper focuses on the creation of a data dense geostatistical model using Transition Probability Geostatistical Software (Carle 1999). Connectivity analysis of the high conductivity facies over many realizations was used to better understand uncertainty when determining suitable recharge sites and rule out a proposed MAR project area if there is little geologic connectivity to the water table. Objectives of this research project are to:

1. Use previously proprietary, newly available geologic conditioning data to create a data-dense, small-scale, fine-resolution geologic model of the possible recharge site.

2. Quantify the potential uncertainty regarding the impact of the heterogeneity of the system.

3. Characterize the connectivity of highly conductive sand and gravel facies in the $\mathrm{X}, \mathrm{Y}$ and $\mathrm{Z}$ directions.

The paper includes a description of the site scale characteristics and monitoring efforts. It then focuses on methods used to create the geologic model and results from a connectivity analysis of the high conductivity facies. Finally, we discuss how to meaningfully use the results from computationally inexpensive analysis of geologic realizations to determine initial viability of recharge sites prior to creating fully functional, computationally expensive groundwater and unsaturated zone flow models. 


\section{Geologic and Site Setting}

The Cosumnes River Basin covers about $3300 \mathrm{~km}^{2}$ and ranges in elevation from sea level to $2400 \mathrm{~m}$ (Fleckenstein 2004). The lower Cosumnes River which is the focus of this specific research project is at elevation close to sea level and is relatively flat. The water table in this region ranges from approximately 20-30 m below ground surface, due to natural winter recharge rebound and agricultural pumping drawdown during the summer growing season (even during the summer irrigation). Groundwater flow is dominantly East to West from the foothills of the Sierra Nevada Mountains to the Sacramento-San Joaquin Delta at sea level. The dominant hydraulic stress on the alluvial aquifer system is groundwater pumping due to seasonal agriculture and the growing ruraldomestic population (Lower Cosumnes Watershed Assessment 2006). The alluvial aquifer extending to the foothills receives mountain front recharge from the Sierra Nevada mountain range which provides groundwater inflow at a very low rate (DWR 1974). During some high intensity rainfall events in the wet season agricultural fields become sufficiently saturated to allow for some deep percolation to the aquifer. However, the Cosumnes River is the most continuous source of recharge during the wet and dry season due to riverbed seepage to the disconnected aquifer. Overall, the aquifer is tending toward overdraft due to the decades of groundwater pumping and low rates of recharge sources.

The upper geology of the Cosumnes area is defined by recent valley alluvium, ranging from high permeability sands and gravels to low permeability silts and clays (DWR 1974). This high permeability alluvium has shown potential for high recharge to the water table in certain areas (DWR 1974; Maples et al. 2019). Beneath the alluvium is the Laguna Formation, which ranges in thickness from $125-200 \mathrm{ft}$ (38-61 m) and consists of non-volcanic sands, silts, and clays. The final formation considered is the Mehrten Formation, which consists of volcanic sands, sands and clays, and ranges in thickness from 200-1200 ft (61-366 m) (DWR 1974). The purpose of this study is to understand how recharged water may move through the system to the upper aquifer, so the focus is on modeling the heterogeneity of the alluvial deposition that most directly impacts recharge to the water table aquifer.

The study site for this project focuses on three vineyards that span approximately six square kilometers in the floodplain between the Cosumnes River and Deer Creek in Elk Grove, CA (see Fig. 3). The local water district received funding for a 10-year project that involved creating a pipeline that can divert up to 6000 acre-feet $\left(7.4 \mathrm{E} 6 \mathrm{~m}^{3}\right)$ of water from the Cosumnes River in the rainy season to these vineyards. Because of permitting issues and lack of flow in the Cosumnes, the first diversion did not occur until January 2021.

This study site shows potential for ideal groundwater banking, based off past work completed in the area (Maples et al. 2019), and the probable existence of IVFs from the American River deposits underneath the modern Cosumnes River (Meirovitz 2010). The vineyards are close to the river, resulting in less expensive infrastructure to bring the water to the site. The topography is relatively flat, which will allow for the diverted water to recharge where desired. The soils also have relatively low salinity, which decreases the potential water quality effects that may occur during large amounts of recharge in one area. Finally, the landowners are interested and invested in the success of this project and have allowed for multiple sampling campaigns and instrument installations.

\section{Methods \\ Data Collection}

When SGMA passed in 2014, California also passed the California Open Water Data Act, requiring the creation of an open-source data base to help in the creation of models for basin groundwater sustainability plans. This data base allowed access to data that was not easily available to the public before. Over 1000 Well Completion Reports (WCR's) available from the California Department of Water Resources database are in the model domain. These WCR's include the lithology of a boring when a new well is drilled, and information on the location of the well and screening depths.

However, the quality of the lithology and information on the well location can vary greatly between reports. For this analysis, only wells in which a unique location could be found were included in the geologic model. Other required criteria for a WCR to be accepted as conditioning data for the model included being legible, having meaningful geologic characterizations (examples of poor characterization include dirt, water, fill, etc.), and representing a portion of the study site that was not already well represented with other WCR's.

From each accepted report, the lithology of the boring was digitized to inform the geologic model. From over 220 classifications, the stratigraphy was simplified to four main facies: gravel, sand, sandy mud, and mud, representative of the key sediment facies of a floodplain depositional environment. These classifications were chosen because they align with the floodplain deposition patterns of the alluvium in the area and follows the characterizations previous researchers used when developing geologic models in the area (Fleckenstein 2004; Meirovitz 2010). From the approximately 1000 available WCR's, 551 were of acceptable quality to be digitized for use in the geologic model. After the accepted reports were digitized and simplified, the lithology was discretized into one-foot $(0.3 \mathrm{~m})$ increments for use in the geologic model, resulting in about 140,000 conditioning data points.

\section{Creation of the Geostatistical Model}

One goal of the project was to generate many data dense, fine resolution geologic realizations that could be used to inform groundwater models and rates of recharge. Transition Probability Geostatistical Software (T-PROGS) was utilized to generate multiple stochastic realizations of the site. T-PROGS utilizes transition probabilities and Markov chains to generate probable 3D properties of the subsurface (Carle 1999).

Unlike certain programs that use training images or variograms to create the geologic models, T-PROGS utilizes a 
transition probability/ Markov chain approach, with transition probability being defined as the probability that a facies will remain the same or transition to another throughout the subsurface (Carle 1999). The flexibility of T-PROGS is that it allows the user to visualize the interaction of the geologic components, gain information on the sequencing of the facies, and supplement that conditioning data with dip/ azimuth angles, mean lengths, proportions, and account for anisotropy in the system (Carle and Fogg 1996; Carle et al. 1998). Past researchers have calculated and revised values for mean lengths, dip and azimuth angles, and other physical characteristics of the Cosumnes site that were utilized in this current geologic model. (Meirovitz 2010; Fleckenstein 2004). One final benefit of using this program is that it will allow for future direct comparison of this smaller scale, significantly more data dense model to other models that existed before (Fleckenstein 2004; Meirovitz 2010; Maples et al. 2019).

Using the data from the WCR's, data driven transition probabilities were calculated. T-PROGS allows the user to choose from five different processes to model the Markov chains for the stochastic model (Carle 1999). In the upward (Z) direction, the Markov chains were generated from the data itself using the discrete lag approach (outlined as method 2 in Carle 1999). These visualizations of the transition probabilities in the upward direction show fining upward sequences and can allow the users to have a better understanding of depositional processes in the system, as is shown in Figure 4, where the probability of transitioning from a coarser facies such as gravel or sand to a finer facies such as sandy mud or mud increases significantly as the lags increase in the upward direction.

\section{Dip (X) Direction}

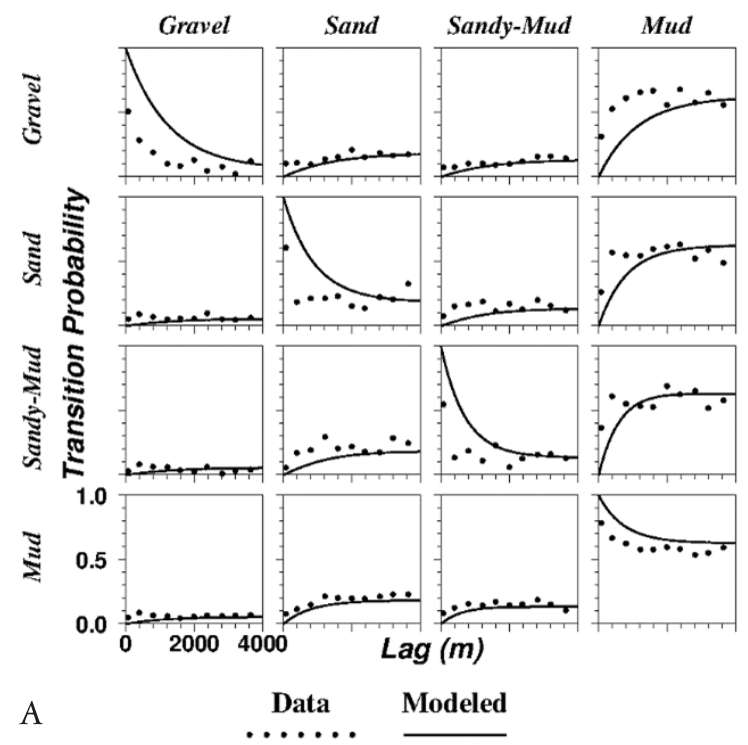

Even with the relatively data-dense scheme, the data density in the $\mathrm{X}$ and $\mathrm{Y}$ direction is not enough to generate as well-defined transition probabilities from the data alone as in the lateral direction (Carle and Fogg 1996; Carle et al. 1998). In this case, instead of using the method of generating Markov chains with the discrete lag approach, an embedded Markov Chain analysis was used (Method 3 in Carle 1999). To generate Markov chains to match the given data, mean lengths for the hydrofacies in the $\mathrm{X}$ and $\mathrm{Y}$ direction were incorporated into the diagonals of the embedded transition probability matrix. The background category, (the category that would most likely fill in unknown gaps) was chosen to be mud because it is the finest facies and has the greatest volumetric proportion in the model. The mean lengths for the strike and dip direction were adapted from previous work completed in the Cosumnes area (Meirovitz 2010). The transition probabilities for the $\mathrm{X}$ and $\mathrm{Y}$ direction, as well as the results from the modeled Markov Chains are given in Figure 1.

The transition probabilities from the data alone are significantly more detailed than lateral transition probabilities with less data. However, as expected, the trends are not nearly as well defined as in the vertical direction. The addition of other geologic knowledge such as mean lengths and volumetric proportions helps to supplement the more sparce lateral geologic data and creates a more informed geologic model.

A summarized table of the values of mean lengths used for each facies for the transition probability matrices is given in Table 1.

Fig. 1 - Transition Probabilities in the Dip (X), (A) and Strike (Y), (B) direction compared to the modeled Markov chains using Method 3 in T-PROGS. The data itself is slightly sporadic but does show general trends. However, the inclusion of subsurface knowledge, such as mean lengths and information from the more data dense $Z$ direction, allows for more informed Markov chain creation.

Fig. 1 - Probabilità di transizione nella direzione Dip (X), (A) e Strike (Y), (B) rispetto alle Markov chains modellate utilizzando il Metodo 3 in T-PROGS. I dati stessi sono leggermente sporadici, ma mostrano tendenze generali. Tuttavia, dati sul sottosuolo, come le lunghezze medie e le informazioni dalla direzione z più densa di dati, consentono di sviluppare una Markov chain con maggiori informazioni. 
Tab. 1 - Values of mean lengths used in Transition Probability matrix for creation of the Markov Chains.

Tab. 1 - Valori delle lunghezze medie utilizzati nella matrice delle probabilità di transizione per la creazione delle Markov chains.

\begin{tabular}{|l|c|c|c|c|}
\cline { 2 - 5 } \multicolumn{1}{c|}{} & $\begin{array}{c}\text { X Direction } \\
(\mathrm{m})\end{array}$ & $\begin{array}{c}\text { Y Direction } \\
(\mathrm{m})\end{array}$ & $\begin{array}{c}\text { Z Direction } \\
(\mathrm{m})\end{array}$ & $\begin{array}{c}\text { Volumetric } \\
\text { Proportions }\end{array}$ \\
\hline Gravel & 1300 & 450 & 3.9 & .056 \\
\hline Sand & 1100 & 450 & 4.1 & .184 \\
\hline Sandy Mud & 800 & 350 & 6.7 & .133 \\
\hline Mud & Background & Background & Background & .627 \\
\hline
\end{tabular}

In the $\mathrm{Z}$ direction, the data alone was used to generate the Markov chains that would be used to generate the stochastic realizations. The Markov chains match the data in the $\mathrm{Z}$ direction fairly well, as shown in Figure 2.

The T-PROGS geostatistical model was conditioned by the 551 simplified well completion reports shown in Figure 3, with a domain $21 \mathrm{~km} \times 12 \mathrm{~km} \times 100 \mathrm{~m}$ and individual cell sizes of $200 \mathrm{~m} \times 200 \mathrm{~m} \times 0.5 \mathrm{~m}$. It is worth noting that the T-PROGS software does not have the capability to account for land elevation, which results in the creation of models with geologic results that are above the land surface. One of the goals of our analysis has been the understand the impact the removal of this data would have on the overall analysis. The data above the land surface is still influenced by the same Markov chain scheme; it just does not physically exist. To see how the removal of this data would affect results of future analysis, the connectivity programs were run both with the inclusion and removal of this data.

\section{Upward (Z) Direction}

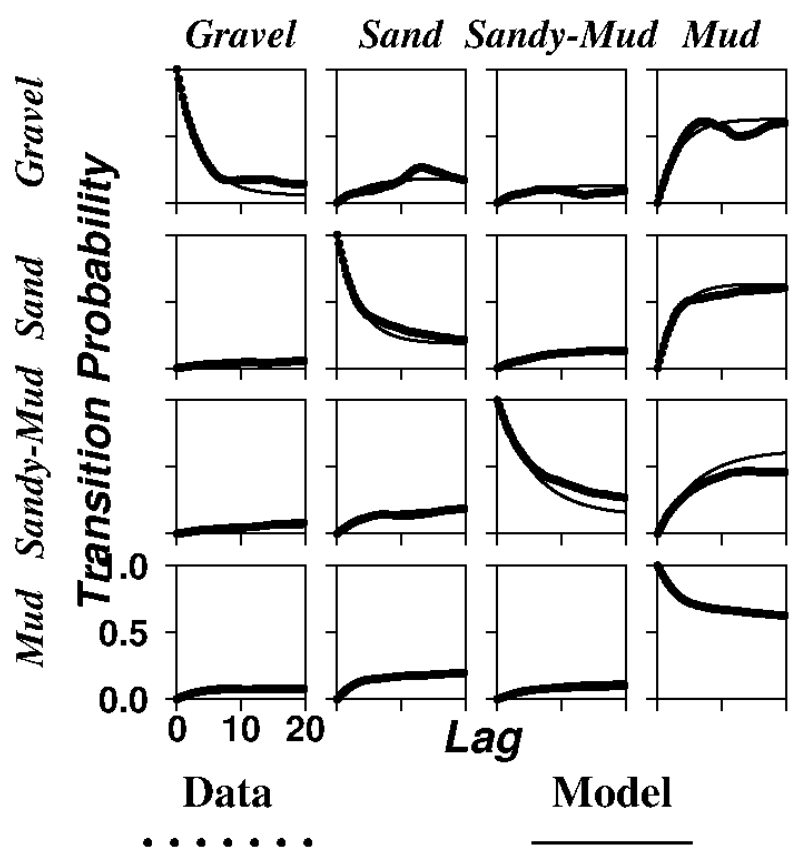

Fig. 2 -Comparison of transition probability graphs from the data itself to the Markov chain models in the $Z$ direction. As shown, the Markov chains are able tofit the transition probabilities generated by the data relatively well.

Fig. 2 - Confronto dei grafici di probabilità di transizione dai dati stessi ai modelli Markov chain nella direzione z. Come mostrato, le Markov chains sono in grado di rappresentare relativamente bene i processi di deposizione dei sedimenti alluvionali.

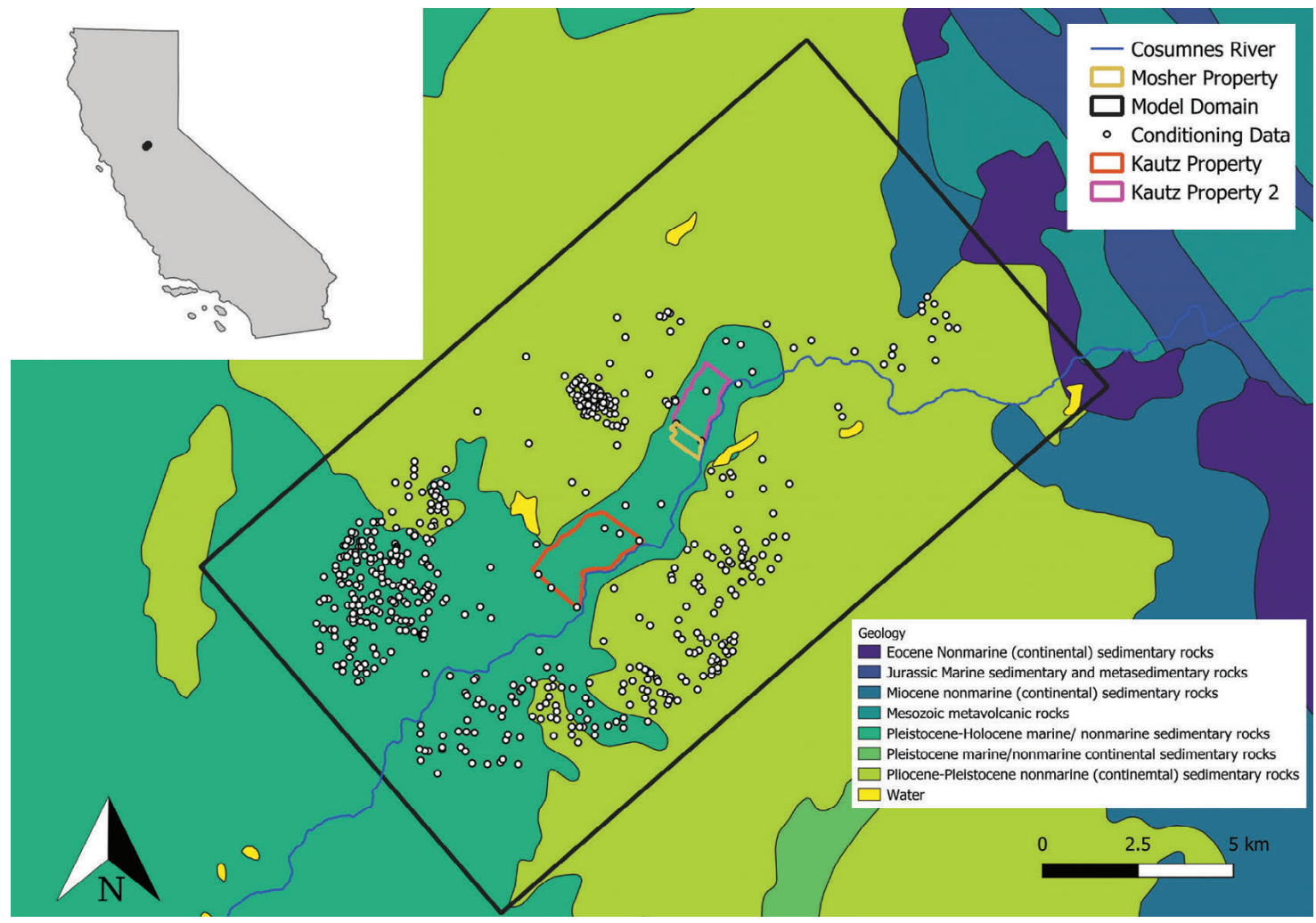

Fig. 3 - Location of 551 WCR's that served as the input data for the geostatistical model in relation to the model domain and three recharge sites.

Fig. 3 - Posizione dei 551 pozzi con informazioni stratigrafiche utilizzati come input per il modello geostatistico sviluppato per I tre siti di ricarica e il modello generale. 


\section{Connectivity Calculations}

When determining how to meaningfully analyze the 100 geologic realizations, the focus was to utilize a metric that would physically quantify the variability in the spatial distribution of the geologic facies which impacts recharge, as opposed to the net facies distributions or bulk geology, which are equal in all realizations. The method chosen was to measure the 3-D connectivity of the highly conductive facies: gravel and sand combined. All geologic realizations generated using T-PROGS are equally probable and are influenced by the same transition probability-Markov chain scheme. However, the location and frequency of highly conductive connected pathways that would allow for recharge to the water table differ throughout realizations (Pardo-Iguzquiza and Dowd 2003). Quantifying the variability in connectivity will allow a better understanding of uncertainty when generating future groundwater models. The software used to analyze connectivity, Connec3D, utilizes the theory outlined in Renard and Allard (2013) and Allard (1994) to calculate connectivity functions of chosen facies in the pure $\mathrm{X}, \mathrm{Y}$, and $\mathrm{Z}$ directions and along the diagonals of the different $3 \mathrm{D}$ planes (Pardo-Iguzquiza and Dowd 2003). In this case, the connectivity function is defined as the probability that two cells belonging to the same facies category are connected when separated by a specified number of lags. The connectivity function is dependent on the type of connectivity considered, the proportion of the analyzed phase, and the method used to create the geologic model. This analysis can be useful in understanding average path lengths in all directions, which can then be translated to understanding the possibility for connection between wells, the potential for recharge to reach the water table, and other analyses. Additionally, this analysis is helpful for understanding basic characteristics of a full model domain and can be useful in deciding if an area should be further explored for a recharge project.
For each realization, the relevant information is the connectivity function, the number of connected components (the number of high conductivity cells in the largest connected pathway), the length of the longest connected pathway in each direction (ranging from a length of one lag to the length of the model domain), and the number of fully percolating pathways in each direction (pathways that span the entire model). For Connec3D, each run spanned 30 lags for each direction. Lag spacing is $200 \mathrm{~m}$ in the $\mathrm{X}$ and $\mathrm{Y}$ directions, and $0.5 \mathrm{~m}$ in the $\mathrm{Z}$ direction.

\section{Results \\ Geostatistical Model}

The Markov chains were used to generate 100 realizations of the subsurface, with cell sizes of $200 \mathrm{~m} \times 200 \mathrm{~m} \times 0.5 \mathrm{~m}$. 100 realizations were chosen to illustrate the variability of geologic facies spatial distribution in results while limiting computational time; 100 realizations took about one day to run. Figure 4 is a 3D representation of all WCR geologic data that informed the geostatistical models. In all realizations, these conditioning data remained the same.

All of the realizations have the same characteristics, such as the proportions and mean lengths of the facies, but the location of specific connected pathways is different with each realization. These visible variabilities that exist from the stochastic process of the models are emphasized in the visualization of four random realizations below (Fig. 5). The geology generated that was above the land surface was removed for these visualizations.

The four realizations were filtered to only show gravel facies, to illustrate the spatial variability in the deposition locations between realizations (Fig. 6). Additionally, visual analysis of the gravel facies in a few realizations demonstrates that the high conductivity facies do not interconnect in a simple horizontally layered format, expected by the law of horizontal

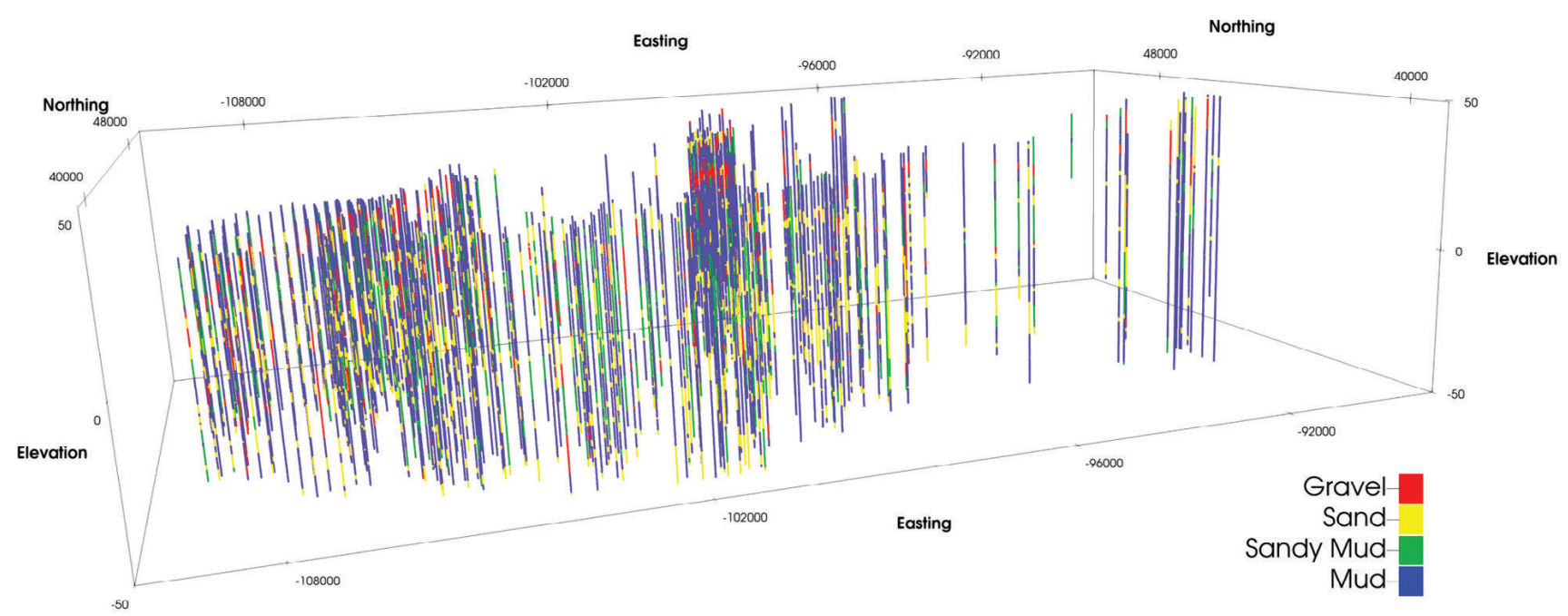

Fig. 4 - Borebole conditioning data that was input into T-PROGS. The data was discretized into 0.5-meter increments and simplified into four facies categories for analysis.

Fig. 4 - Dati di condizionamento dei pozzi inseriti in T-PROGS. I dati sono stati discretizzati in incrementi di 0,5 metri e semplificati in quattro categorie di facies per l'analisi. 

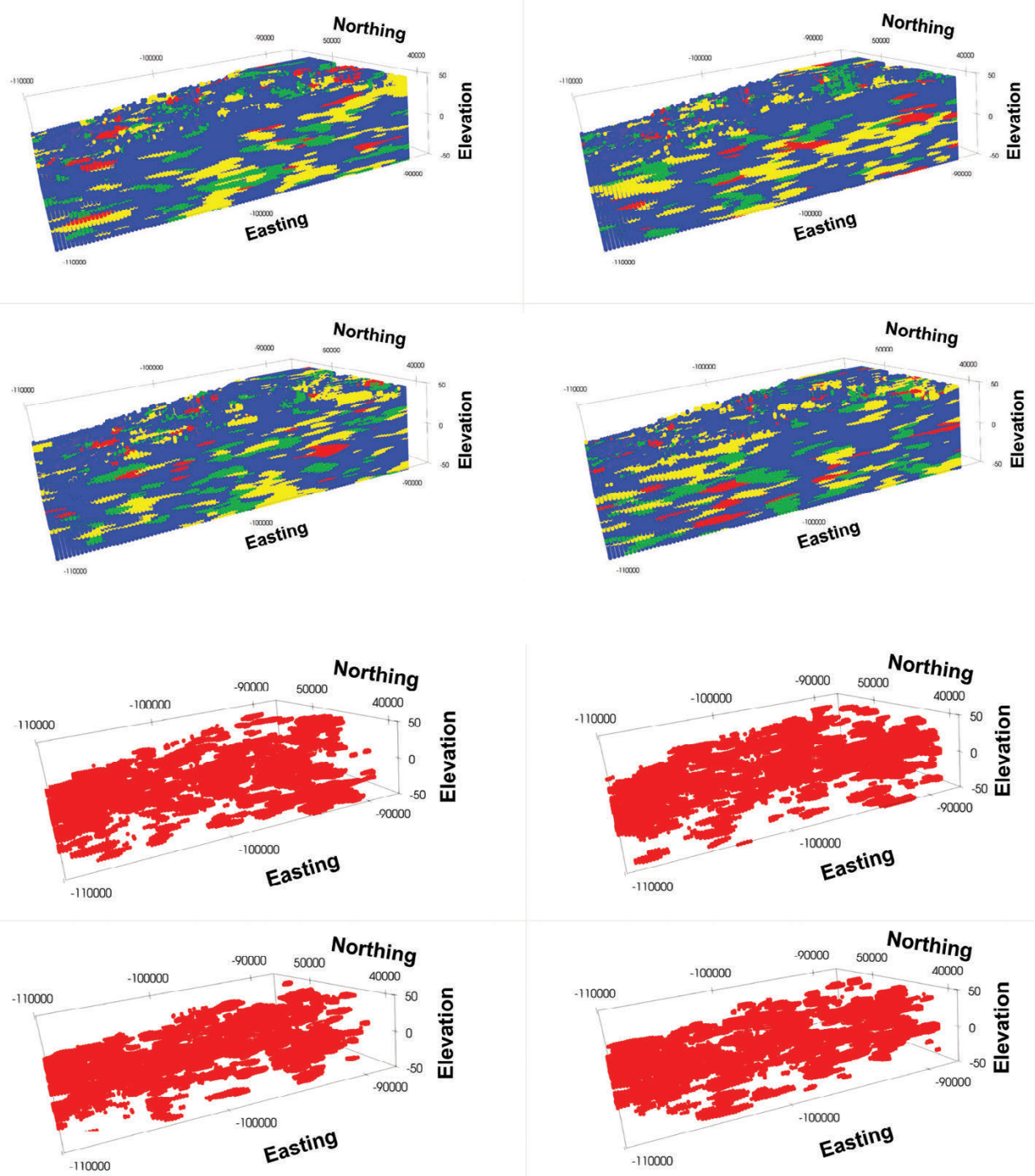

Fig. 5 - Visual representation of four realizations of the model domain. Each realization utilizes the same conditioning data.

Fig. 5 - Rappresentazione grafica di quattro realizzazioni del dominio del modello. Ogni realizzazione utilizza gli stessi dati di condizionamento. deposition, but branches out in all three dimensions creating a continuous aquifer system. These interconnected pathways of sands and gravels are expected to increase the productivity of MAR to the upper semi-confined aquifer.

\section{6- and 18-Point Connectivity Results}

The program was run for all 100 realizations at 18-point connectivity (faces and edges) with the data above the land surface included and excluded. The connectivity function for the $\mathrm{x}, \mathrm{y}$, and $\mathrm{z}$ direction over 30 lag distances was exported and plotted. 18-point connectivity analysis was chosen to be presented here because 6-point was seen as too limiting. The 18-point analysis would be more realistic for how water would travel through the system.

The resulting graphs are shown in Figures 7-9. To better visualize the spread in values, the five realizations with the lowest connectivity functions at 30 lags are visualized in blue and the five realizations with the highest connectivity functions at 30 lags are visualized in red. Figure 7 shows the connectivity function at each lag for 18- point connectivity in the $\mathrm{X}$ direction with the geology above the land surface included (Fig. 7A) and without (Fig. 7B). The connectivity results for both figures drop significantly within the first few lags and then begin to stabilize. However, the connectivity results in Figure $7 \mathrm{~A}$ have less spread, and less jumps in connectivity results between lags.

Figure 8 shows the connectivity function at each lag for 18- point connectivity in the $\mathrm{Y}$ direction with the geology above the land surface included (Fig. 8A) and excluded (Fig. $8 \mathrm{~B})$. Unlike the $\mathrm{X}$ direction results, the connectivity function with the inclusion of the geology above the land surface dips down to a low point overall around a lag distance of 3000 meters, and then slightly increases (Fig. 8A). This drop in connectivity in the $\mathrm{Y}$ direction lines up with the location of the floodplain, which is expected to have a higher proportion of fines on average and have greatest connection in the $\mathrm{X}$ direction. When this geology above the land surface is removed (Fig. 8B), there are some oscillations in connectivity function results, with slightly more overall spread than Figure 8A. 

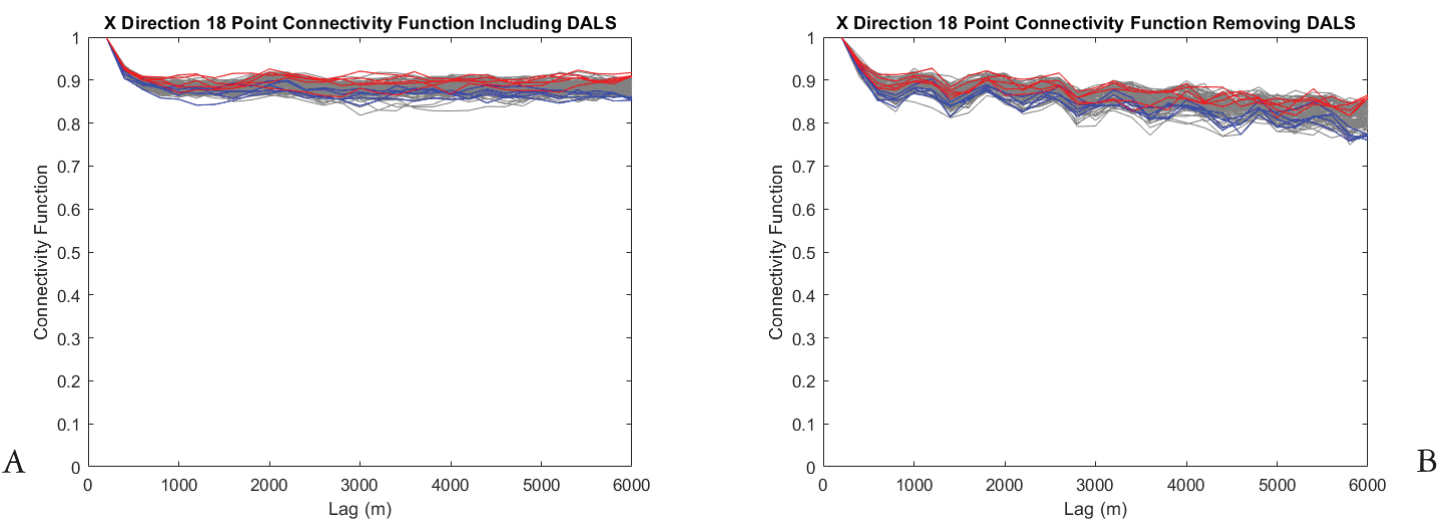

Fig. 7 - Plots of Connectivity Functions in the X direction for all 100 realizations using 18- point connectivity (A) with the inclusion of data above the land surface (DALS), (B) without the inclusion of DALS.

Fig. 7 - Grafici di funzioni di connettività nella direzione X per tutte le 100 realizzazioni utilizzando la connettività a 18 punti con i dati al di sopra del livello topografico inclusi (A) o esclusi (B).
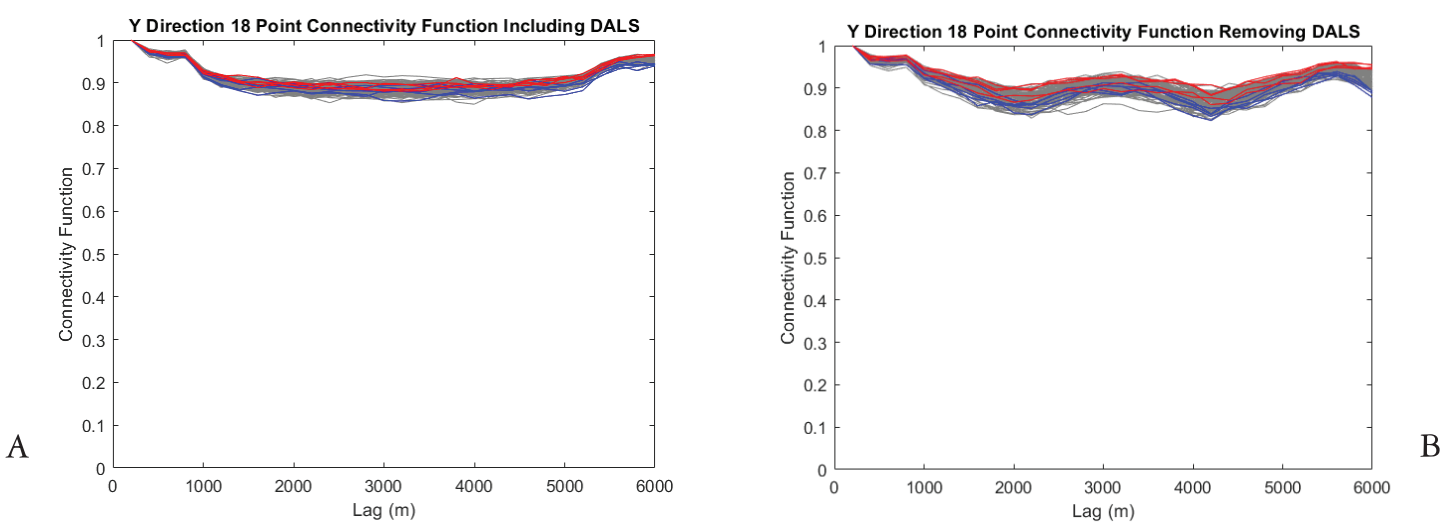

Fig. 8 - Plots of Connectivity Functions in the $Y$ direction all 100 realizations using 18- point connectivity (A) with the inclusion of data above the land surface (DALS) (B) without the inclusion of DALS.

Fig. 8 - Grafici delle funzioni di connettività nella direzione Y per tutte le 100 realizzazioni utilizzando la connettività a 18 punti con i dati al di sopra del livello topografico inclusi (A) o esclusi (B).

Figure 9 shows the connectivity function at each lag for 18 - point connectivity in the $\mathrm{Z}$ direction with the geologic data above the land surface included (Fig. 9A) and excluded (Fig. 9B). In both cases, the connectivity function steadily decreases as lag distance increases, and the spread of results between realizations is smaller. Also, the connectivity function is much smoother due to a significantly smaller lag distance of 0.5 meters per lag as compared to $200 \mathrm{~m}$ individual lag distances in the $\mathrm{X}$ and $\mathrm{Y}$ direction. It appears that overall, the removal or inclusion of the geologic data above the land surface affects results in the $\mathrm{Z}$ direction the least.
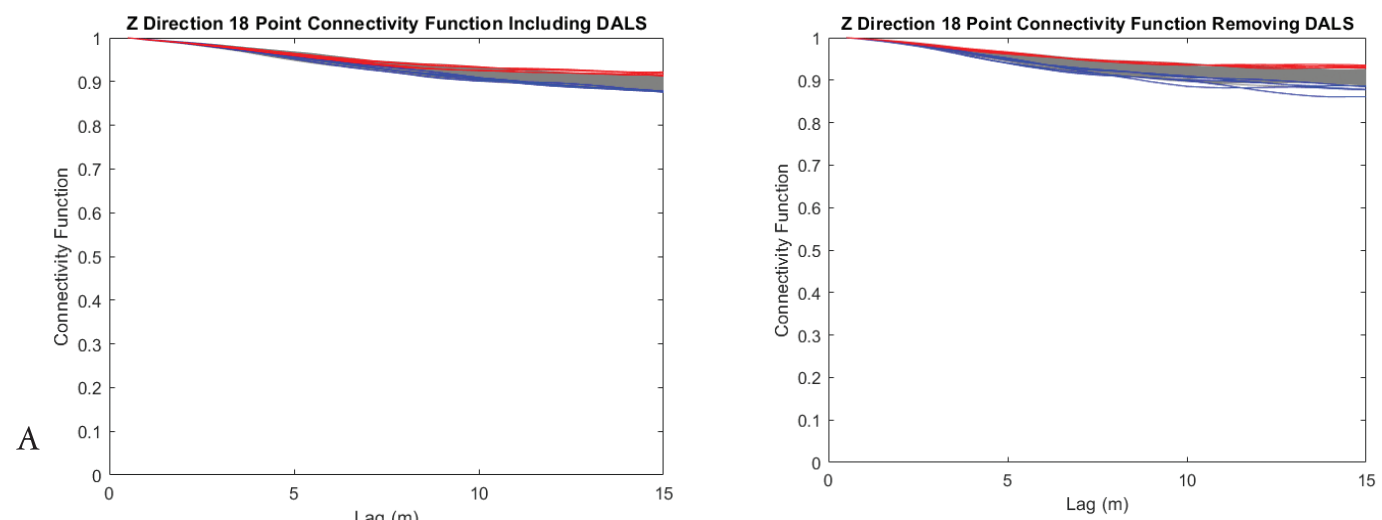

B

Fig. 9 - Plots of Connectivity Functions in the $Z$ direction for all 100 realizations using 18-point connectivity (A) with the inclusion of data above the land surface (DALS) (B) without the inclusion of DALS.

Fig. 9 - Grafici delle funzioni di connettività nella direzione $\mathrm{Z}$ per tutte le 100 realizzazioni che utilizzano la connettività a 18 punti con i dati al di sopra del livello topografico inclusi (A) o esclusi (B). 
Statistics of the number of percolating components, connected components, and max length of the connected pathways in the $\mathrm{X}, \mathrm{Y}$, and $\mathrm{Z}$ direction for the 6 - and 18 - point connectivity are summarized in Table 2 below.

Tab. 2 - Summarized Table of Results for Relevant Characteristics for 18 Point Connectivity Analysis with the inclusion of data above the land surface (DALS) and without the inclusion of DALS.

Tab. 2 - Tabella riassuntiva dei risultati per le caratteristiche rilevanti per l'analisi della connettività a 18 punti con i dati al di sopra del livello topografico inclusi o esclusi.

\begin{tabular}{|c|c|c|c|c|c|c|c|c|c|c|}
\hline & \multicolumn{2}{|c|}{ AVERAGE } & \multicolumn{2}{|c|}{ MEDIAN } & \multicolumn{2}{|c|}{ STD DEVATION } & \multicolumn{2}{|c|}{ MINIMUM } & \multicolumn{2}{|c|}{ MAXIMUM } \\
\hline & $\begin{array}{l}18 \text { point } \\
\text { with } \\
\text { DALS }\end{array}$ & $\begin{array}{l}18 \text { Point } \\
\text { Without } \\
\text { DALS }\end{array}$ & $\begin{array}{l}18 \text { point } \\
\text { with } \\
\text { DALS }\end{array}$ & $\begin{array}{l}18 \text { Point } \\
\text { Without } \\
\text { DALS }\end{array}$ & $\begin{array}{l}18 \text { point } \\
\text { with } \\
\text { DALS }\end{array}$ & $\begin{array}{l}18 \text { Point } \\
\text { Without } \\
\text { DALS }\end{array}$ & $\begin{array}{l}18 \text { point } \\
\text { with } \\
\text { DALS }\end{array}$ & $\begin{array}{l}18 \text { Point } \\
\text { Without } \\
\text { DALS }\end{array}$ & $\begin{array}{l}18 \text { point } \\
\text { with } \\
\text { DALS }\end{array}$ & $\begin{array}{l}18 \text { Point } \\
\text { Without } \\
\text { DALS }\end{array}$ \\
\hline $\begin{array}{l}\text { X Percolating } \\
\text { Components }\end{array}$ & 1 & 0.03 & 1 & 0 & 0 & 0.17 & 1 & 0 & 1 & 1 \\
\hline Y Percolating Components & 1 & 1.05 & 1 & 1 & 0 & 0.22 & 1 & 1 & 1 & 2 \\
\hline Z Percolating Components & 1 & 1.03 & 1 & 1 & 0 & 0.17 & 1 & 1 & 1 & 2 \\
\hline $\begin{array}{l}\text { Number of Connected } \\
\text { Components }\end{array}$ & 3285.67 & 4201.42 & 3295.00 & 4174.00 & 178.52 & 266.14 & 2812.00 & 3621.00 & 3729.00 & 4870.00 \\
\hline Max X Length (in pixels) & 105.00 & 92.38 & 105.00 & 92.50 & 0 & 4.23 & 105 & 84 & 105 & 105 \\
\hline Max Y Length (in pixels) & 60 & 60 & 60 & 60 & 0 & 0 & 60 & 60 & 60 & 60 \\
\hline Max Z Length (in pixels) & 200 & 200 & 200 & 200 & 0 & 0 & 200 & 200 & 200 & 200 \\
\hline $\begin{array}{l}\text { Proportion of High K } \\
\text { Facies }\end{array}$ & 0.23 & 0.21 & 0.23 & 0.21 & 0 & 0 & 0.23 & 0.20 & 0.23 & 0.22 \\
\hline
\end{tabular}

\section{Discussion}

This MAR study site is unique because of the extensive amount of previous knowledge and ongoing data collection available for Cosumnes River area. In most cases of MAR projects, it is unlikely that there will be as much time or resources available to explore all possible characteristics of the site to determine feasibility and success of the project. However, in our case, the large amount of data, the current groundwater level monitoring network, and other previous studies completed allows for an in-depth exploration of the subsurface, which in turn can be used in the analysis of the uncertainty in the initial model results and can provide insights on how to account for that uncertainty when creating groundwater models to simulate future scenarios (both climate change and management scenarios). One hundred realizations of the subsurface model were generated for this area to better understand how the stochastic nature of this method of geologic model creation could help understanding the hydrogeological properties of the system and, therefore, affect management decisions when determining recharge rates because of the spread in connectivity function results for all directions.

For all realizations, the facies proportions are constant, and the realizations visually show the same depositional patterns. However, the differences are evident when looking at individual facies because in each realization, the location of these high-conductivity (i.e., gravel and sand) pathways vary. The location and prevalence of these high-conductivity facies are extremely important when beginning to determine the potential success of a recharge project. If there is no connection from the top of the subsurface to the water table, it is unlikely that the recharge project will be successful.
Using a computationally inexpensive analysis method such as connectivity of the high-conductivity facies allows for an understanding of the uncertainty between realizations and can also give some initial insight into the potential for recharge in the area.

When analyzing the metrics outlined in Table 2, the number of fully percolating components in each direction is helpful for understanding the magnitude of potential pathways that would allow water to travel fully through the domain. The maximum length of components in each direction allows understanding how far it can reasonably be expected for water to travel through the high-conductivity facies in the domain. The proportion of high-conductivity facies was included to emphasize that throughout all realizations, the proportions of all facies remained the same. It is worth noting however, that the proportion of these high $\mathrm{K}$ facies changed slightly whether the geologic data above the land surface was included or excluded (21\% vs 23\%). Future studies are needed to determine where on the land surface in the model domain are locations of connectivity and percolation components as a way to strategically locate places for efficient MAR events. This may involve combining connectivity analyses with spatial weighting of other factors, such as infiltration rates, access to water for recharge, and depth to the water table. In addition, rather than conducting analyses for the entire depth of a primary aquifer, focusing analyses on the depth to water may be most useful and less computationally expensive. This connectivity analysis can also be completed on smaller sections of the model domain in which recharge projects are more feasible, such as near the river or in areas with large amounts of open land. Smaller sections can then be analyzed for full percolation in the $\mathrm{Z}$ direction to test in which parts of 
the domain surface recharge will benefit those near where the recharge occurred.

One of the objectives of calculating connectivity functions for all 100 realizations was to better understand the variability in connectivity between realizations in all directions, but mainly in the $\mathrm{Z}$ direction, because we want to have a better understanding of the potential for recharge to the water table. This included analyzing the variability in connectivity functions and quantifying the number of realizations that had fully percolating components as compared to the realizations that did not have fully percolating components. In the case of this domain, all realizations for 18-point connectivity had at least one fully percolating component in the $\mathrm{Y}$ and $\mathrm{Z}$ direction, with full percolation in the $\mathrm{X}$ direction for all realizations in which the geologic data above the land surface was included in the analysis. This gives great confidence that somewhere in the domain, there is a site that would result in effective recharge to the bottom of the model domain $(50 \mathrm{~m}$ below ground level). The connectivity functions vary in all realizations, which can be used to quantify the uncertainty in the geologic model between realizations using a metric that directly affects recharge efficiency. The spread of results in the connectivity function decreased when the geologic data above the land surface was included versus when it was removed. In the $\mathrm{Z}$ direction specifically, the direction that is most important for recharge potential, the connectivity function at 30 lags varied from 0.87-0.92 when the geologic data above the land surface was included and 0.86-0.94 when the geologic data above the land surface was removed. This uncertainty can be accounted for by incorporating the five most and least connected realizations (highlighted in red and blue in Fig. 9) into fully developed groundwater models that can track water flow through the system. Another option would be to perform more specified connectivity analysis on just the most and least connected realizations, in which connectivity analysis are performed on the most probable areas for recharge projects. This would allow us to calculate groundwater recharge via the groundwater flow model and calculate the range of recharge potential to determine whether a location would be efficient as a recharge site. When moving to the creation of groundwater models that are intended to give stakeholders confidence in results, understanding the uncertainty of the underlying geology, and utilizing the realizations that will capture that uncertainty the most (such as the most and least connected realizations) will give stakeholders the full picture of potential connectivity results without the need to run one hundred groundwater models.

It is worth noting that Harter (2005) analyzed percolation averages for correlated random fields, which concluded a proportion of $12.6 \%$ high-conductivity facies could theoretically create full percolation. However, this was for a much larger lattice that did not include real geologic data and did not account for potential anisotropy in the system. This $12.6 \%$ result for full percolation was also calculated as a percolation average, meaning that at a facies proportion of $12.6 \%$, there is a $50 \%$ probability of full percolation. We do recognize though, that with a proportion of highly conductive facies at over $20 \%$, full percolation in all directions should be expected. When utilizing Connec $3 \mathrm{D}$, the removal of the geologic data above the land surface required all data above the land surface to be labeled as low conductivity facies, which we believe arbitrarily inflated the impact of the low conductivity facies on the probability analysis for the connectivity function. Because the cross-sectional area for flow in the $\mathrm{X}$ direction is significantly smaller than that of flow in the $\mathrm{Y}$ direction, we also believe that the removal of the geologic data above the land surface impacted the $\mathrm{X}$ direction significantly more than the $\mathrm{Y}$ direction.

The geologic model created for this connectivity analysis was informed by significantly more data than what is normally available for potential recharge sites. Because of this, the variability between realizations shown in the connectivity functions is relatively low. In addition, our proportion of highly conductive facies in the area is well above the percolation threshold of $12.6 \%$, which further decreases the potential variability between realizations. While this connectivity analysis for our site was still useful to instill confidence in our geologic results, and understand the slight variability between realizations, we recognize that this type of analysis would be significantly more useful in areas where the geology is not so certain, and where the proportion of highly conductive facies is closer to the percolation threshold. Regardless of how much information is included in the geologic model, the connectivity function results are still useful, because the vertical connectivity results can show whether creating a fully functioning groundwater flow model would at least yield some favorable results when locating areas of recharge that would locally reach the water table. The connectivity analysis can also provide a quick preliminary evaluation for sites where there is not time to develop a full groundwater model. Provided some further refinements, a future goal is to develop a full set of guidelines on how to best evaluate MAR sites locally, with the possibility of extension to other sites with similar geologic characteristics.

\section{Conclusion}

This research is focused on emphasizing the value of creating extensive geologic realizations that can be utilized to gauge the potential future success of a MAR project. By spending focused time in the beginning stages of a project determining the geology of the site and by performing initial connectivity analyses of the site, it could potentially be efficiently determined if a site will not be suitable for recharge. In this study 100 stochastic geologic realizations were informed by high resolution geologic observational data to look at the variability of highly conductive pathways in alluvial aquifer unit systems. Connec3D was used to determine connectivity characteristics of all 100 realizations for 18-point connectivity with and without the inclusion of data above the land surface. For all 100 realizations in both cases, there was at least one fully percolating component from the top of the model to the bottom, suggesting that there is some place within the model 
domain in which recharged water will reach the water table. The variability in the connectivity functions can be used in the future to strategically choose which geologic realizations (specifically the most and least connected realizations) to incorporate into groundwater models that can track water flow throughout the system, especially for recharge locations in when there is not a significant amount of geologic knowledge and the proportion of highly conductive facies is close to the percolation threshold of $12.6 \%$ for correlated fields. Further analysis is needed to determine where in the model domain recharge will be the most beneficial by combining connectivity analysis with spatial weighting of other factors such as infiltration rates, ease of water access, and depth to the water table. With a depth to water of around $20 \mathrm{~m}$ in the area, this work emphasizes the importance of incorporating the heterogeneity into a groundwater flow model for scenario runs, because in most cases, a recharge project that has not accounted for deeper geology will not yield the greatest success possible. Initial geologic modeling and connectivity analysis can give stakeholders confidence that a MAR project will yield efficient and effective recharge results.

Competing interest

The authors declare no competing interest.

Additional information

Supplementary information is available for this paper at

https://doi.org/10.7343/as-2021-500

Reprint and permission information are available writing to

acquesotterranee@anipapozzi.it

Publisher's note Associazione Acque Sotterranee remains neutral with regard to jurisdictional claims in published maps and institutional affiliations.

\section{REFERENCES}

Allard D (1994) Simulating a Geological Lithofacies with Respect to Connectivity Information Using the Truncated Gaussian Model (pp. 197-211). https://doi.org/10.1007/978-94-015-8267-4_16

Bachand PAM, Roy SB, Choperena J, Cameron D, Horwath WR (2014) Implications of using on-farm flood flow capture to recharge groundwater and mitigate flood risks along the Kings River, CA Environmental Science and Technology, 48(23), 13601-13609. https://doi.org/10.1021/es501115c

Barlow PM, Leake SA (2012) Circular 1376 Groundwater Resources Program Streamflow Depletion by Wells-Understanding and Managing the Effects of Groundwater Pumping on Streamflow.

Carle SF (1999) T-PROGS: Transition Probability Geostatistical Software. University of California, Davis, 78.

Carle SF, Labolle EM, Weissmann GS, Brocklin DVan, Fogg GE (1998) Conditional Simulation of Hydrofacies Architecture: A Transition Probabiility/ Markov Approach. Hydrogeologic Models of Sedimentary Aquifers, Special Publication, 147-170. https://doi. org/10.2110/sepmcheg.01.147

Cayan D, Dettinger M, Stewart I, Knowles N (2005) Recent changes toward earlier springs-early signs of climate warming in western North America. Watershed Management Council Networker, 3-7.

Dahlke HE, Brown AG, Orloff S, Putnam D, O'Geen T (2018) Managed winter flooding of alfalfa recharges groundwater with minimal crop damage. California Agriculture, 72(1), 65-75. https:// doi.org/10.3733/ca.2018a0001

Dillon P, Kumar A, Kookana R, Leijs R, Reed D, Parsons S, Ingleton G (2009) Managed aquifer recharge-risks to groundwater dependent ecosystems-A review. Land and Water Australia, Canberra.

Fleckenstein JH (2004) Modeling River-Aquifer Interactions and Geologic Heterogeneity in an Alluvial Fan System, Cosumnes River, CA. Dissertation, University of California, Davis.

Fogg GE, Carle SF, Green C (2000) Connected-network paradigm for the alluvial aquifer system. Special Paper of the Geological Society of America, 348, 25-42. https://doi.org/10.1130/0-8137-2348-5.25

Harter T (2005) Finite-size scaling analysis of percolation in threedimensional correlated binary Markov chain random fields. Physical Review E - Statistical, Nonlinear, and Soft Matter Physics, 72(2). https://doi.org/10.1103/PhysRevE.72.026120

Jiménez Cisneros BE, Oki T, Arnell NW, Benito G, Cogley JG, Döll P, Jiang T, Mwakalila SS (2014) Freshwater resources. In: Climate Change 2014: Impacts, Adaptation, and Vulnerability. Part A: Global and Sectoral Aspects. Contribution of Working Group II to the Fifth Assessment Report of the Intergovernmental Panel on Climate Change [Field CB, VR Barros, DJ Dokken, KJ Mach, MD Mastrandrea, TE Bilir, M Chatterjee, KL Ebi, YO Estrada, RC Genova, B Girma, ES Kissel, AN Levy, S MacCracken, PR Mastrandrea, LL White (eds.)]. Cambridge University Press, Cambridge, United Kingdom and New York, NY, USA, pp. 229269.

Kocis TN, Dahlke HE (2017) Availability of high-magnitude streamflow for groundwater banking in the Central Valley, California. Environmental Research Letters, 12(8), 84009.

Lower Cosumnes River Watershed Assessment. (2006) https://www.cosumnes.org/wp-content/uploads/2015/05/ LowerCosumnesWatershedAssessment.pdf

Maples SR, Fogg GE, Maxwell RM (2019) Modeling managed aquifer recharge processes in a highly heterogeneous, semi-confined aquifer system. Hydrogeology Journal, 27(8), 2869-2888. https://doi. org/10.1007/s10040-019-02033-9

Meirovitz C D (2010) Influence of American River incised valley fill on Sacramento County hydrogeology. Thesis. University of California, Davis.

O’Geen AT, Saal MBB, Dahlke H, Doll D, Elkins R, Fulton A, Fogg G, Harter T, Hopmans JW, Ingels C, Niederholzer F, Solis SS, Verdegaal P, Walkinshaw M (2015) Soil suitability index identifies potential areas for groundwater banking on agricultural lands. California 
Agriculture. https://doi.org/10.3733/ca.v069n02p75 of Water Resources, D. (1975). California's Groundwater: Bulletin No. 118.

Pardo-Igúzquiza E, Dowd PA (2003) CONNEC3D: A computer program for connectivity analysis of $3 \mathrm{D}$ random set models. Computers and Geosciences, 29(6), 775-785. https://doi. org/10.1016/S0098-3004(03)00028-1

Renard P, Allard D (2013) Connectivity metrics for subsurface flow and transport. Advances in Water Resources, 51, 168-196. https://doi. org/10.1016/j.advwatres.2011.12.001

Sneed M, Brandt JT (2015) Land subsidence in the San Joaquin Valley, California, USA, 2007-2014. Proceedings of the International Association of Hydrological Sciences, 372, 23-27. https://doi. org/10.5194/piahs-372-23-2015

Sustainable Groundwater Management Act, and related provisions (as chaptered) Sustainable Groundwater Management Act. (n.d.).

Swain DL, Langenbrunner B, Neelin JD, Hall A (2018) Increasing precipitation volatility in twenty-first-century California. Nature Climate Change, 8(5), 427-433.

Taylor RG, Scanlon B, Döll P, Rodell M, Van Beek R, Wada Y, Longuevergne L, Leblanc M, Famiglietti JS, Edmunds M, others. (2013) Ground water and climate change. Nature Climate Change, 3(4), 322-329.

Waterhouse H, Bachand S, Mountjoy D, Choperena J, Bachand PAM, Dahlke HE, Horwath WR (2020) Agricultural managed aquifer recharge - water quality factors to consider. https://doi.org/10.3733/ ca.2020a0020

Weissmann GS, Zhang Y, Fogg GE, Mount JF (2004) Influence of Incised-Valley-Fill Deposits on Hydrogeology of A StreamDominated Alluvial Fan. Aquifer Characterization, 15-28. https:// doi.org/10.2110/pec.04.80.0015 